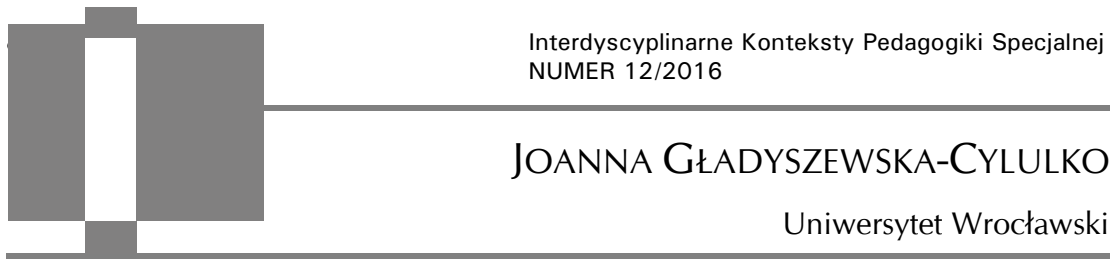

\title{
Osobowościowe uwarunkowania procesu emancypacji osób z niepełnosprawnością wzrokową
}

\begin{abstract}
Joanna Gładyszewska-Cylulko, Osobowościowe uwarunkowania procesu emancypacji osób z niepetnosprawnościq wzrokowa [Personality factors of the emancipation of people with visual disabilities]. Interdyscyplinarne Konteksty Pedagogiki Specjalnej, nr 12, Poznań 2016. Pp. 119-133. Adam Mickiewicz University Press. ISSN 2300-391X
\end{abstract}

The purpose of the study was to find out the relationship between personality factors and tendency to emancipation. The author focuses on the most important problems of personality of persons with visual disabilities. She wonders why do certain factors of personality encourage the process while others slow it down. The process of emancipation is complex and long-lasting but very significant not only from the perspective of people with visual disabilities, but also for all the people in a community that respect diversity.

Key words: emancipation, personality, people with visual disabilities

Pragnienie emancypacji jest niewątpliwie istotne dla szeroko rozumianego zdrowia człowieka. Dzięki niemu podmiot może otwarcie wyrażać swoje zdanie, podejmować decyzje w oparciu o własny, niepowtarzalny system wartości, cele życiowe, pragnienia i dążenia, realizować działania mające na celu przekształcanie siebie i otoczenia. Wszystko to sprzyja osiąganiu stanu przystosowania społecz- 
nego i ułatwia funkcjonowanie $w$ otoczeniu. Jednak pragnienie wyzwolenia, wyemancypowania się nie występuje u każdego człowieka. Jego powstanie uzależnione jest od wielu czynników. Według Marii Czerepaniak-Walczak możemy mówić o wychowaniu do emancypacji, poprzez stwarzanie warunków sprzyjających osiąganiu własnej wolności i autonomii. Dokonuje się to m.in. poprzez rozwój pewnych cech osobowościowych, takich jak otwartość, odwaga, poczucie godności ${ }^{1}$. Jednak dążenia emancypacyjne mogą zostać osłabione przez ograniczenia obyczajowe (w tym także mity i stereotypy), czynniki organizacyjne lub cywilizacyjne, a także niektóre czynniki tkwiące w osobowości człowieka, jak choćby lęk, poczucie izolacji i osamotnienia ${ }^{2}$. I właśnie takie osobowościowe uwarunkowania procesu emancypacji są przedmiotem moich rozważań w niniejszym artykule. Ponieważ w centrum moich zainteresowań badawczych znajduje się człowiek z niepełnosprawnością wzrokową, na nim właśnie skupię się, omawiając wyżej zarysowaną problematykę.

Do tej pory badaczom nie udało się wyodrębnić charakterystycznych cech osobowości osób niewidomych. Wielu z nich uważa, że nie ma różnicy $w$ tym względzie między osobami pełnosprawnymi a niepełnosprawnymi wzrokowo. Według Zofii Sękowskiej

defekt wzroku powoduje dwa rodzaje oddziaływania na osobowość. $\mathrm{Z}$ jednej strony wywiera presję na niewidomego, co uwidaczniać się może $\mathrm{w}$ zmianach zachowania osoby, czasem $\mathrm{w}$ zachowaniach odbiegających od ogólnie obowiązujących standardów, z drugiej zaś strony osobowość może oznaczać typ reakcji i zachowania na sam fakt braku lub utraty wzroku. Na tym tle rysują się dwa rodzaje ujęć tego zagadnienia. Jedna grupa badaczy problemu stwierdza, że inwalidztwo wzrokowe jest przyczyną kształtowania się zaburzonej osobowości, a druga, że taki stan rzeczy nie ma miejsca ${ }^{3}$.

${ }^{1}$ M. Czerepaniak-Walczak, Pedagogika emancypacyjna, rozwój świadomości krytycznej człowieka, GWP, Gdańsk 2006, s. 79-80.

2 M. Czerepaniak-Walczak, Między dostosowaniem a zmiana. Elementy emancypacyjnej teorii edukacji, Wydawnictwo Naukowe Uniwersytetu Szczecińskiego, Szczecin 1995, s. 247-251.

3 Z. Sękowska, Przystosowanie społeczne młodzieży niewidomej, WSiP, Warszawa 1991, s. 51. 
Zwolennicy pierwszego ze stanowisk wspomnianych powyżej przez Sękowską skłonni są przypuszczać, że takie cechy istnieją. Niestety, brak jest kompleksowych badań potwierdzających te słowa. Co prawda były one prowadzone, ale ich autorzy skupiali się na poszczególnych komponentach osobowości - jej cechach (np. potrzebach, postawach, zdolnościach) i wymiarach (np. aktywności, samodzielności, agresywności) lub też odnosili się do jednej, wybranej grupy wiekowej. Warto wspomnieć w tym miejscu o badaniach zrealizowanych przez Waldemara Klinkosza. Ich główne pytanie brzmiało: Jakie znaczenie dla sukcesu akademickiego młodzieży niepełnosprawnej wzrokowo ma ich osobowość? Albo inaczej: jakie zmienne osobowościowe $\mathrm{w}$ rozumieniu psychologicznym odgrywają istotną rolę dla poziomu osiągnięć uniwersyteckich studentów inwalidów wzroku? Autor przeprowadził analizę porównawczą średnich wyników studentów niewidomych i słabowidzących ze studentami widzącymi (za pomocą testu f-Studenta). Doprowadziła ona do wniosku, że czynnikiem istotnie różnicującym badane grupy pod względem zmiennych osobowościowych i typu relacji interpersonalnych jest zakres dysfunkcji wzroku (stopień niedowidzenia). Jeśli chodzi o hipotezę ogólną (która dotyczyła powiązań między osiągnięciami akademickimi i wybranymi, zbadanymi zmiennymi osobowościowymi), to została ona zweryfikowana pozytywnie, choć $\mathrm{w}$ różnym stopniu $\mathrm{w}$ grupach studentów niewidomych, słabowidzących i widzących. Natomiast hipotezy szczegółowe, zakładające powiązania sukcesu akademickiego $\mathrm{z}$ osobowością studentów inwalidów wzroku, potwierdziły się częściowo. Uzyskane wyniki $w$ grupie studentów niewidomych, słabowidzących i widzących wskazują na inną konfigurację cech osobowości istotnych dla poziomu ich osiągnięć 4 . Można więc powiedzieć na podstawie tych badań, że o ile możemy wyodrębnić pewne specyficzne cechy osobowości warunkujące sukces akademicki osób niewidomych (np. ciekawość poznawcza, umiejętność współpracy z ludźmi, kon-

${ }^{4}$ W. Klinkosz, Sukces akademicki studentów niewidomych $i$ słabo widzących a ich osobowość, Towarzystwo Naukowe KUL, Lublin 2003, s. 190. 
centrowanie się na wyznaczonych celach i zadaniach, akceptacja wad i niedoskonałości innych ludzi), to w przypadku osób słabowidzących można mówić z mniejszym prawdopodobieństwem o istnieniu takich specyficznych cech. Badania nie potwierdziły ponadto przypuszczenia o istnieniu cechy lub cech osobowości będących predykatorem pozwalającym przewidywać osiągnięcia akademickie studentów niewidomych i słabowidzących. Nie potwierdzono przykładowo hipotezy istnieniu pozytywnej zależności między poziomem osiągnięć akademickich studentów niewidomych i słabo widzących a wewnętrzną lokalizacją kontroli. Warto zauważyć, że $\mathrm{w}$ grupie badanych osób $\mathrm{z}$ niepełnosprawnością wzrokową istnieją różnice nie tylko $\mathrm{w}$ zależności od stopnia niepełnosprawności wzrokowej, ale również płci. Przykładowo niewidome studentki $\mathrm{w}$ porównaniu $\mathrm{z}$ ich widzącymi koleżankami są optymistyczniej nastawione do życia, sumienne, otwarte, kreatywne, chętne do pomocy, w razie potrzeby asertywne i stanowcze, a jednocześnie delikatne i niepewne. Natomiast studenci niewidomi różnią się od ich widzących rówieśników takimi cechami jak małe zdecydowanie, duża niepewność i unikanie kontaktów z innymi ${ }^{5}$.

Zdarzało się też, że badacze swoje poglądy opierali nie na badaniach, ale logicznych wywodach podpartych różnymi teoriami osobowości. Jako przykład mogą posłużyć słowa Tadeusza Witkowskiego, który pisze, że:

Gdyby zgodzić się z psychologami humanistycznymi, że najbardziej podstawową potrzebą jest potrzeba aktualizacji siebie, aktualizacja własnych potencjalności, to trzeba przewidywać, że niedowidzęnie może stanowić źródło poważnych problemów w sferze osobowościowej ${ }^{6}$.

Zanim podejmę próbę ukazania osobowościowych uwarunkowań procesu emancypacji, pragnę przybliżyć nieco problematykę

${ }^{5}$ Ibidem, s. 157-171.

6 T. Witkowski, Rozumieć problemy osób niepetnosprawnych. 13 rodzajów niepetnosprawności, MDBO, Warszawa 1993, s. 67. 
osobowości, pokazać, jakie czynniki mogą wpływać na jej kształtowanie i rozwój.

Na problem właściwości człowieka można patrzeć z wielu perspektyw w zależności od przyjmowanej teorii osobowości. Wśród autorów nie ma zgodności nie tylko co do jednej koncepcji osobowości, ale także co do kryteriów grupowania teorii jej dotyczących. Warta przytoczenia wydaje mi się w tym miejscu propozycja zasad wyróżniania kategorii teorii osobowości formułowana przez Henryka Gasiula7. Proponuje on trzy linie wiodące:

- wymiar „od cech podmiotu do ich sposobu spełniania w interakcji",

- wymiar „od jedności z otoczeniem ku własnej tożsamości” (,powszechność -indywidualność”),

- wymiar "stabilność - zmienność".

Autor zwraca uwagę na uwzględnienie rodzaju interakcji z kulturą, społecznością, innymi osobami, a także interakcji pomiędzy wersjami „ja” w świadomości podmiotu. Najbardziej podstawowymi teoriami osobowości są według niego teorie cech, a więc takie, które opisują i wyjaśniają zachowania poprzez odwoływanie się do względnie trwałych dyspozycji człowieka. Cechy osobowości zależne są od jednostkowych właściwości psychofizycznych (np. właściwości temperamentu). Ale i w tych teoriach można zauważyć różnice w wymiarze "stabilność - zmienność”. Cechy mogą być traktowane jako struktury niezmienne lub jako interakcyjne. Interakcja jest według autora podstawą ujawniania się osobowości, stąd też szczególne znaczenie nadaje on tym teoriom, które podkreślają różnego rodzaju interakcje. Proponuje zastosowanie do nich kryterium „powszechne - jednostkowe” (czyli wymiar „od jedności $\mathrm{z}$ otoczeniem $\mathrm{ku}$ własnej tożsamości"). Powszechność rozumiana jest jako podleganie wszystkich ludzi danego typu interakcjom umożliwiającym np. przystosowanie się do warunków życia w środowisku (tu można umieścić teorie ujęte w ramach psychologii

${ }^{7}$ H. Gasiul, Psychologia osobowości. Nurty, teorie, koncepcje, Difin, Warszawa 2006, s. 57. 
ewolucyjnej, teorie kulturowe czy aktywistyczno-regulacyjne). Przeciwstawnością powszechności jest indywidualność, którą opisują przede wszystkim teorie wyrastające $\mathrm{z}$ psychologii humanistycznej ${ }^{8}$. Teorie cech mają swoje ważne miejsce w tyflopedagogice. Jeden z czołowych polskich tyflopedagogów, Tadeusz Majewski, podaje, że osobowość jest zorganizowanym i dynamicznym zespołem cech psychicznych, które powodują, że człowiek zachowuje się w pewien sposób. Określone zachowania są inicjowane przez pewne wewnętrzne siły (cechy osobowości) i mają charakterystyczny dla każdej osoby przebieg zgodnie z jej indywidualnymi cechami osobowości 9 . Można znaleźć odniesienie między takim spojrzeniem na osobowość a teoriami cech zwanymi inaczej teoriami deskryptywnymi. Za podstawę uznano $\mathrm{w}$ nich fakt istnienia względnej stałości pewnych elementów zachowania się człowieka w podobnych sytuacjach, a także podobieństwo i regularność zachowań różnych ludzi pozwalające wnioskować o wspólności ich cech i opisywać je za pomocą tych samych pojecć. Określona konfiguracja cech stanowi zatem strukturę osobowości, sama cecha zaś jest determinantą i skrótowym opisem zachowań człowieka ${ }^{10}$. Majewski w zaprezentowanej definicji osobowości podkreśla dynamiczność i zmienność jako jej ważny atrybut. Aspekt dynamiczności uwypukla też Gordon Willard Allport, którego zdaniem osobowość jest procesem mającym pewne cechy stałe, ale podlegającym mimo to ciągłym zmianom, indywidualizujacym się. Jego teoria "zakłada niepowtarzalność każdej osoby, podkreśla wagę świadomych zachowań i intencji, które wyjaśniają, nadają znaczenie wszelkim działaniom człowieka"11. Podstawową jednostką osobowości jest według niego cecha rozumiana jako skłonność ukierunkowująca działanie. W tym

${ }^{8}$ Ibidem, s. 58.

${ }^{9}$ T. Majewski, Tyflopsychologia rozwojowa (Psychologia dzieci niewidomych $i$ stabowidzacych), "Zeszyty tyflologiczne” nr 20, Redakcja Wydawnictw Tyflologicznych PZN, Warszawa 2002, s. 263.

${ }^{10}$ B. Grabski, J.K. Gierowski, Zaburzenia osobowości - różne spojrzenia i próby ich integracji, „Psychiatria Polska” 2012, tom XLVI, nr 5, s. 834.

${ }^{11}$ H. Gasiul, op. cit., s. 85. 
miejscu warto wtrącić, iż działania człowieka nie są tylko wynikiem czy przejawem cech jego osobowości, ale ich przyczyny mogą tkwić $\mathrm{np}$. w przejawianych nawykach lub postawach. Allport ${ }^{12}$ rozróżnia wyraźnie pojęcie cechy (która może być właściwa wielu osobom) od dyspozycji osobistej (która jest właściwa tylko jednej osobie). Cecha łączy ludzi wychowanych w różnych kulturach, społecznościach itp., ale są oni niepowtarzalni, gdyż mają różne dyspozycje osobiste. Niektóre dyspozycje (zwane kardynalnymi) są tak silne, że nasycają każdy akt zachowania człowieka, choć czasem trudno je jednoznacznie nazwać. Inne, tzw. dyspozycje osobiste zasadnicze, wskazują na cechy charakterystyczne danej osoby i dają się nie tylko łatwo rozpoznać, ale i skonkretyzować (np. mówimy, że osoba jest impulsywna, bałaganiarska). Jeszcze inne, nazwane przez niego dyspozycjami osobistymi wtórnymi, ujawniają się tylko w określonych okolicznościach. Jednak oceniając wpływ dyspozycji na zachowanie, należy zauważyć, że jest ono determinowane nie tylko cechami czy dyspozycjami, ale i sytuacją, która je wyzwala, intencjami i zamiarami jednostki wyrażającymi się w postaci pragnień, ambicji, aspiracji. Allport proponuje wprowadzenie określenia „proprium” na oznaczenie podmiotowości i własności. Każdy z podstawowych aspektów proprium pojawia się w konkretnym okresie życia i charakteryzuje się w określony sposób. I tak np. poczucie tożsamości pojawia się już w drugim roku życia, a jego podstawą są relacje $z$ innymi osobami. Szacunek do samego siebie to aspekt proprium pojawiający się rok później, wyraża się on w poczuciu niezależności, osiągnięć, w dumie z samego siebie i miłości do siebie. Obraz własnej osoby kształtuje się przede wszystkim między czwartym a szóstym rokiem życia i opiera się na podstawie „ja pożądanego" i „ja niepożądanego". Zawiera on dwa aspekty: spostrzegane aktualnie zdolności oraz aspiracje. Natomiast samoświadomość, odgrywająca wielką rolę w procesie emancypacji, pojawia się $\mathrm{w}$ wieku dorosłym i jest efektem finalnym zaistnienia wszystkich aspektów proprium, to znaczy poczucia własnego ciała, poczu-

12 Ibidem, s. 87. 
cia tożsamości, szacunku do siebie samego, rozszerzania „ja”, obrazu własnej osoby, racjonalnego myślenia i dążeń osobistych ${ }^{13}$.

Podstawą istnienia przypuszczenia, że osoby niepełnosprawne wzrokowo mogą mieć jakieś cechy osobowości/dyspozycje odróżniające ich od osób pełnosprawnych wzrokowo jest fakt, iż jedynie niektóre cechy osobowości mają charakter wrodzony. Pozostałe rozwijają się w zależności od doświadczeń życiowych danej osoby. Zatem to, czego doświadcza osoba z niepełnosprawnością wzrokową w czasie swego życia, może wpłynąć na formowanie się u niej pożądanych lub niepożądanych cech osobowości. Myślę, że mogę zaryzykować twierdzenie, że niepełnosprawność wzrokowa nie ma bezpośredniego wpływu na powstanie pewnych cech i wymiarów osobowości, ale może wpływać na to w sposób pośredni poprzez wywoływanie określonych postaw ze strony otoczenia społecznego. Postawy społeczeństwa przejawiające się w zachowaniu wobec osób niepełnosprawnych wzrokowo mogą zaś wpływać na ich stosunek do siebie i kształtować obraz samego siebie. W zapobieganiu tworzenia niewłaściwych cech osobowości dziecka niewidomego ogromną rolę odgrywają niewątpliwi rodzice. Stanley Coopersmith wykazał, że takie pozytywne cechy osobowości jak wysokie poczucie własnej wartości i silne zaufanie do siebie, występujące u dzieci niepełnosprawnych wzrokowo, korelowały z takimi cechami osobistymi ich rodziców jak ambitne oczekiwania, akceptacja, opiekunczość, szacunek do sprzecznych z ich przekonaniami opinii swoich dzieci, poczucie własnej wartości ${ }^{14}$.

Podczas swego życia człowiek dąży do uspójnienia spostrzeżeń na własny temat (czyli autoweryfikacji), a także uspójnienia tych spostrzeżeń z informacjami pochodzącymi z zewnątrz (czyli autowaloryzacji). Celem takich działań jest dążenie do bycia uważanym za takiego, jakim się jest albo się myśli, że takim się jest. To dążenie do spójności daje poczucie integralności wewnętrznej, likwiduje napięcie związane $\mathrm{z}$ niepewnością, umożliwia przewidywanie wła-

13 Ibidem, s. 88.

14 W. Klinkosz, op. cit., s. 64. 
snych zachowań. Dlatego też człowiek wybiera te sytuacje, które potwierdzają jego wyobrażenia na własny temat, nawet jeśli powodują one konieczność zaakceptowania negatywnych opinii ${ }^{15}$. Zdarza się jednak nierzadko, że dążenie do spójności wchodzi w konflikt z potrzebą autowaloryzacji. Jest to szczególny rodzaj konfliktu, zważywszy, że potrzeba spójności jest potrzebą poznawczą, a potrzeba autowaloryzacji - emocjonalną. William B. Swann nazywa go konfliktem poznawczo-afektywnym. Badacz uważa, że mimo wszystko potrzeba autoweryfikacji jest silniejsza. Jako dowód można przytoczyć eksperyment, w którym dwie grupy osób (o wysokiej i niskiej samoocenie) wybierały partnerów na podstawie opinii tych osób na temat badanych. Zgodnie z hipotezą weryfikacji osoby badane oceniające się pozytywnie wybierały partnerów, którzy mieli o nich również pozytywne zdanie. Oceniający się negatywnie zaś wybierali tych, którzy ich oceniali negatywnie ${ }^{16}$. Samowiedza jest jednym z najważniejszych, jeśli nie najważniejszym, wyznaczników poczucia tożsamości. Tożsamość człowieka formułuje się równocześnie poprzez obserwacje i refleksję - człowiek m.in. dokonuje oglądu świata, obserwuje reakcje otoczenia w stosunku do siebie samego i poddaje to refleksji tworząc własną tożsamość. Tożsamość osobista może być rozumiana jako doświadczanie siebie samego jako niepowtarzalnej jednostki różniącej się od innych. Taka tożsamość wiąże się z podziałem świata społecznego na kategorie „ja inni" i wyodrębnieniem wiedzy o własnych cechach najsilniej różniących ,ja” od „innych” w grupie. Można mówić jeszcze o tożsamości społecznej, która jest doświadczaniem siebie samego jako członka grupy, z którą człowiek się identyfikuje ${ }^{17}$. Badacze zajmujący się problematyką osobowości osób niewidomych i słabo widzących uważają, że większe problemy z określeniem swej przynależności mają osoby słabowidzące. T. Kończyk na podstawie badań

15 L. A. Pervin, Psychologia osobowości, GWP, Gdańsk, 2005, s. 259.

16 Ibidem, s. 260-261.

17 B. Wojciszke, Człowiek wśród ludzi. Zarys psychologii społecznej, Wydawnictwo naukowe Scholar, Warszawa, 2002, s. 473-474. 
zmierzających do ustalenia różnic w akceptacji swej niepełnosprawności przez osoby niewidome i słabowidzące podaje, że niewidomi mniej odczuwają swoje kalectwo, bardziej je akceptują, gdyż mają mniejsze możliwości zauważania niewłaściwych reakcji otoczenia, ale przede wszystkim nie mają dylematu identyfikacyjnego wynikającego niepełnosprawności wzrokowej (,jestem niewidomy czy widzący?"), jaki jest udziałem osób słabowidzących ${ }^{18}$. Do podobnych wniosków doszedł Tadeusz Witkowski ${ }^{19}$, który na podstawie przeprowadzonych przez siebie badań uważa, że nasilenie problemów w sferze osobowości jest wyższe u osób słabowidzących niż niewidomych. Podaje on, że trudna sytuacja, wnikająca z braku wzroku, wymaga od człowieka wykształcenia w sobie i wykazywania się pewnymi cechami osobowości. Ponadto osoby te ujawniają potrzebę rozwoju, tak więc z pełnym zaangażowanie pokonują trudności na swej drodze, starając się, by ich niepełnosprawność była jak najmniej dostrzegana w społeczeństwie. Może to powodować powstawanie takich zachowań jak np. podejmowanie się zadań niezwykle trudnych do zakończenia sukcesem z uwagi na ograniczenia wynikające $\mathrm{z}$ niepełnosprawności wzrokowej, czego konsekwencją jest nierzadko przeciążanie wzroku, a nawet doprowadzanie do pogorszenia jego stanu. Choć trudności nie są traktowane jako klęska, lecz jak wyzwanie, to jednocześnie mają one poczucie rozgoryczenia i doświadczają swojej inności w działaniu. Zdarza się również, że ujawniają pewne zarzuty w stosunku do siebie, takie jak np. brak silnej woli czy niedostateczne wykorzystanie czasu. Niepełnosprawność wzrokowa jest jedną z cech definiujących człowieka wchodzącą w skład jego poczucia tożsamości. Nie może być ona uznawana przez niego jako nadrzędna, ale nie może on jej też całkowicie odrzucać, zaprzeczać jej istnieniu. Gdy człowiek niewidomy czy słabowidzący nie akcep-

18 T. Kończyk, Wptyw niedowidzenia na ksztattowanie się osobowości inwalidów wzroku III grupy, „Biuletyn Zespołu Wizytatorów Metodyków Zakładów Rehabilitacji Zawodowej Inwalidów" 1980, nr 23, s. 9-17.

19 T. Witkowski, op. cit. 
tuje tego, że ma pewne ograniczenia związane z zaburzeniami widzenia, to nie może ich przezwyciężać, pracować nad nimi, korygować ich i kompensować, słowem - nie funkcjonuje tak dobrze, jakby mógł. Ponadto takie zachowanie sprzyja powstawaniu licznych mechanizmów obronnych, takich jak np. zaprzeczanie, projekcja, rezygnacja, ucieczka w fantazjowanie. Istnienie ich nie świadczy o nieprawidłowościach, jeśli jednak człowiek stosuje je często, może to być sygnałem istniejących problemów w sferze jego osobowości. Pragnę $\mathrm{w}$ tym miejscu wspomnieć o znaczeniu jednej z podstawowych cech osobowości, jaką jest postawa względem samego siebie i własnej niepełnosprawności. Aby dziecko mogło wykształcić adekwatną, pozytywną samoocenę, niezbędny jest właściwy poziom samowiedzy. Jednym z komponentów wiedzy o sobie omawianych osób jest to, że są one niewidome lub słabowidzące. Takiej wiedzy dzieci niepełnosprawne wzrokowo nabywają stosunkowo szybko, bo już w wieku 4-5 lat. Oczywiście nie jest to zdarzenie jednorazowe, lecz proces, który zaczyna się jeszcze wcześniej, ale w tym wieku mają one już tą samowiedzę i jednocześnie mają potrzebę uzyskania informacji na temat różnych aspektów swej niepełnosprawności ${ }^{20}$. Od tego, jakich informacji i w jaki sposób dostarczy im otoczenie, zależeć będzie ich stosunek do tego aspektu wiedzy o sobie. Ale poczucie własnej wartości, wiara w siebie czy poczucie bezpieczeństwa pojawia się wtedy, gdy zaspokojone są podstawowe potrzeby emocjonalne - miłości, przynależności i szacunku²1.

Myślę, że w przypadku osób z niepełnosprawnością wzrokową, zwłaszcza słabowidzących, może być również tak, że ich motywacja do działania wynika z niewłaściwych pobudek (jak np. udowodnienie pełnosprawnemu społeczeństwu, że nie są gorsze w tym, co robią), powodowana jest pragnieniem realizacji niezaspokojonych potrzeb szacunku i uznania. Według Abrahama Maslowa „podstawowe potrzeby ludzkie są zorganizowane w hierarchię o względnej

20 T. Majewski, op. cit., s. 266.

21 A. Maslow, Motywacja i osobowość, PWN, Warszawa 2009, s. 91. 
dominacji”22. Oznacza to, że gdy tylko zostaną zaspokojone niższe potrzeby, natychmiast pojawiają się wyższe i to one stanowią siłę napędową do działania. Jeśli jednak potrzeby niższego rzędu nie zostały zaspokojone (nie chodzi tu o pełne zaspokojenie, ale zaspokojenie $\mathrm{w}$ takim stopniu, żeby potrzeba ta nie domagała się realizacji), dominują one w organizmie i wyznaczają jego zachowanie. Maslow podaje też, że

jednostki, których pewna potrzeba była zawsze zaspokojona, są najlepiej przygotowane do radzenia sobie $\mathrm{z}$ deprywacją danej potrzeby w przyszłości. Ponadto osoby, które doświadczyły deprywacji w przeszłości, będą inaczej reagować na obecnie zaspokojenie potrzeby niż ktoś, kto nigdy nie zaznał deprywacji ${ }^{23}$.

W hierarchii potrzeb najniżej znajdują się potrzeby fizjologiczne, następnie są potrzeby bezpieczeństwa, przynależności i miłości, szacunku i samorealizacji. Im wyżej znajduje się dana potrzeba, tym później pojawia się w życiu człowieka i tym mniej gwałtowniej domaga się spełnienia. $W$ tym miejscu warto jednak wspomnieć, że o ile potrzeby niższego rzędu wygasają albo zostają uśpione po ich zaspokojeniu, o tyle potrzeby samorealizacji wraz z ich zaspokajaniem wzrastają lub myślę, że można powiedzieć: pogłębiają się. O ile zaspokojenie potrzeb niższego rzędu wywołuje poczucie ulgi i odprężenia, to zaspokojenie potrzeb będących na szczycie hierarchii może wyzwolić stan euforii, oszałamiającego szczęścia, ekstazy. Dążenie do ich zaspokojenia prowadzi do rozwoju silnego, autentycznego indywidualizmu. Co więcej, taki indywidualizm nie stoi w sprzeczności z pozytywnymi emocjami do innych. Można nawet powiedzieć, że im bardziej poznaje się, darzy szacunkiem i rozwija siebie, tym bardziej kocha się i szanuje innych ${ }^{24}$.

Dla powstania i urzeczywistniania dążeń emancypacyjnych niezbędne jest poczucie podmiotowości, a więc stan, w którym czło-

\footnotetext{
22 Ibidem, s. 65.

23 Ibidem.

24 Ibidem, s. 67.
} 
wiek jest przeświadczony, że jest podmiotem w relacji ze światem przedmiotowym, że jest twórcą zdarzeń, stanów, autorem znaczeń i że stopień, w jakim jest takim twórcą jest zgodny z oczekiwanymi lub posiadanymi w tym zakresie standardami ${ }^{25}$. Podmiotowość człowieka przejawia się „przez jego aktywność w otoczeniu, którego człowiek jest częścią, przez uczestnictwo człowieka w zdarzeniach, które $\mathrm{w}$ danej sytuacji przebiegają i które przekształcają tę obiektywną sytuację w inną" 26 .

Niewątpliwie człowiek niewidomy z uwagi na różnego rodzaju ograniczenia wynikające $\mathrm{z}$ nieprawidłowości w obrębie narządu wzroku jest narażony częściej na trudne sytuacje, które są dla niego przyczyną pojawiania się stresu. Pozornie proste czynności, niesprawiające problemów człowiekowi widzącemu (np. przejście przez zatłoczony trotuar) dla osoby niewidomej mogą być trudne. Warto w tym momencie dodać, że do stresorów środowiska fizycznego można zaliczyć m.in.: oświetlenie, hałas, drgania i wibracje. Osoby niewidome i słabowidzące narażone są zwłaszcza na ten pierwszy stresor. Gdy oświetlenie jest niedostateczne, wykonywane czynności trwają zwykle dłużej. Także nadmiar światła (olśnienia) jest bardzo źle odbierany przez człowieka ${ }^{27}$. Długotrwały lub często przeżywany stres wywołuje różnego rodzaju niepożądane psychologiczne reakcje. Janusz Reykowski28, odwołując się do badań prowadzonych przez różnych autorów, podaje, że taki stres może wpływać niekorzystnie na przebieg czynności motorycznych, per-

${ }^{25}$ K. Korzeniowski, Podmiotowość człowieka. Metateoretyczne ramy teorii, [w:] Podmiotowość jednostki w koncepcjach psychologicznych i organizacyjnych, red. K. Korzeniowski, R. Zieliński i W. Daniecki, Wydawnictwo Ossolineum, Wrocław - Warszawa - Kraków - Gdańsk - Łódź 1983, s. 55-56.

26 B. Bokus, O warunkach narracji stwarzanych dziecku przez dorostego (w świetle rozważań na temat podmiotowości matego dziecka w sytuacji wychowawczej), [w:] Podmiotowość w doświadczeniach wychowawczych dzieci i młodzieży, red. A. Gurycka, M. Kofta, Wydawnictwo Uniwersytetu Warszawskiego, Warszawa 1989, s. 95.

27 A. Bańka, Społeczna psychologia środowiskowa, Wydawnictwo Naukowe Scholar, Warszawa 2002, s. 187-189.

${ }^{28} \mathrm{~J}$. Reykowski, Funkcjonowanie osobowości w warunkach stresu psychologicznego, PWN, Warszawa 1966, s. 224-232. 
cepcję rzeczywistości (choć tu zdania autorów są podzielone, niektórzy mówią także o facytującym działaniu stresu), może powodować wycofanie, lęk, wzrost ogólnego napięcia emocjonalnego. Ma również wpływ na stosunki międzyludzkie. Choć zdarza się, że pod wpływem stresu następuje wzrost zachowań afiliatywnych, to gdy jest on silny i długotrwały, daje skutek odwrotny. Dla omawianego $\mathrm{w}$ niniejszym artykule problemu znaczenie ma także wpływ stresu na motywację człowieka. Badacze są zgodnie w tym względzie, iż stres powoduje zaburzenia motywacji. Przejawiają sią one „W formie apatycznego reagowania na przebieg zdarzeń i braku zainteresowani wynikiem własnych działań (...) utrata motywacji pod wpływem stresu jest zjawiskiem, które cechuje silne napięcie występujące w całym zachowaniu sią podmiotu"29. Ostatecznie stres ma wpływ na osobowość człowieka, choć nie do końca jest jasne, czy dotyczy to wszystkich jej obszarów.

Czynniki osobowościowe, choć wpływają na przebieg jednostkowych emancypacji podejmowanych przez osoby $\mathrm{z}$ niepełnosprawnością, nie są z pewnością jedynymi faktorami wzmacniającymi lub osłabiającymi proces emancypacji. Prócz nich ważny jest także przebieg procesu edukacji, oddziaływanie bliskich kręgów społecznych czy różnego rodzaju instytucji i organizacji. Ale nie sposób ich pominąć w zgłębianiu problematyki wyzwalania się od zależności i zdobywania satysfakcjonującego miejsca w społeczeństwie.

\section{Bibliografia}

Bokus B., O warunkach narracji stwarzanych dziecku przez dorosłego (w świetle rozważań na temat podmiotowości matego dziecka w sytuacji wychowawczej), [w:] Podmiotowość w doświadczeniach wychowawczych dzieci i młodzieży, red. A. Gurycka, M. Kofta, Wydawnictwo Uniwersytetu Warszawskiego, Warszawa 1989.

Bańka A., Społeczna psychologia środowiskowa, Wydawnictwo Naukowe Scholar, Warszawa 2002.

${ }^{29}$ Ibidem, s. 257. 
Czerepaniak-Walczak M., Między dostosowaniem a zmianą. Elementy emancypacyjnej teorii edukacji, Wydawnictwo Naukowe Uniwersytetu Szczecińskiego, Szczecin 1995.

Czerepaniak-Walczak M., Pedagogika emancypacyjna, rozwój świadomości krytycznej człowieka, GWP, Gdańsk 2006.

Gasiul H., Psychologia osobowości. Nurty, teorie, koncepcje, Difin, Warszawa 2006.

Grabski B., Gierowski J. K., Zaburzenia osobowości - różne spojrzenia i próby ich integracji, „Psychiatria Polska” 2012, tom XLVI, nr 5, s. 829-844.

Klinkosz W., Sukces akademicki studentów niewidomych $i$ stabo widzących a ich osobowość, Towarzystwo Naukowe KUL, Lublin 2003.

Kończyk T., Wptyw niedowidzenia na ksztattowanie się osobowości inwalidów wzroku III grupy, „Biuletyn Zespołu Wizytatorów Metodyków Zakładów Rehabilitacji Zawodowej Inwalidów" 1980, nr 23, s. 9-17.

Korzeniowski K., Podmiotowość człowieka. Metateoretyczne ramy teorii, [w:] Podmiotowość jednostki w koncepcjach psychologicznych i organizacyjnych, red. K. Korzeniowski, R. Zieliński i W. Daniecki, Wydawnictwo Ossolineum, Wrocław Warszawa - Kraków - Gdańsk - Łódź 1983.

Majewski T., Tyflopsychologia rozwojowa (Psychologia dzieci niewidomych $i$ słabowidzacych), "Zeszyty tyflologiczne” nr 20, Redakcja Wydawnictw Tyflologicznych PZN, Warszawa 2002.

Maslow A., Motywacja i osobowość, PWN, Warszawa 2009.

Pervin L. A., Psychologia osobowości, GWP, Gdańsk 2005.

Reykowski J., Funkcjonowanie osobowości w warunkach stresu psychologicznego, PWN, Warszawa 1966.

Sękowska Z., Przystosowanie społeczne młodzieży niewidomej, WSiP, Warszawa 1991.

Witkowski T., Rozumieć problemy osób niepetnosprawnych. 13 rodzajów niepetnosprawności, MDBO, Warszawa 1993.

Wojciszke B., Człowiek wśród ludzi. Zarys psychologii społecznej, Wydawnictwo naukowe Scholar, Warszawa 2002. 